\title{
PENGARUH KOMPONEN ALOKASI DANA DESA DAN PRODUK DOMESTIK REGIONAL BRUTO TERHADAP TINGKAT KEMISKINAN KABUPATEN /KOTA DI PROVINSI ACEH
}

\author{
Yusniati, Murhaban, Khaddafi \\ PPIM Universitas Malikussaleh, Lhokseumawe
}

\begin{abstract}
Village Fund Allocation is funds originating from the APBN allocated to villages, used to finance village administration, implementation of village development, community development, and empowerment of village communities, in order to alleviate poverty. The purpose of this study was to analyze the effect of village fund allocation for rural development, village community development, empowerment of rural communities and gross regional domestic product on the poverty level of districts / cities in Aceh Province. This research is quantitative using panel data consisting of cross-sectional data, namely 23 regencies / cities with 3-year time series data. Data analysis method is panel data regression using eviews tools. The results of the study showed that the allocation of village funds for village development and village community development had a negative effect on poverty levels. Whereas the allocation of village funds to empower rural communities and gross regional domestic products does not affect the level of poverty. This indicates that the use of village funds prioritizes village development. Furthermore, the overall results of the study indicate that all independent variables simultaneously have a simultaneous effect on the level of poverty. Village fund allocation should not only focus solely on village development. Because the development of the quality of human resources must also get the same portion as the allocation of village funds for development, so that with the advancement of development will be in line with improving the quality of good human resources.
\end{abstract}

\section{Keyword : Components, village funds, gross regional domestic products, poverty}

\section{PENDAHULUAN}

Kemiskinan merupakan permasalahan sosial kompleks yang terjadi di setiap negara. Kemiskinan merupakan bagian dari krisis ekonomi, dimana krisis ekonomi merupakan salah satu aspek yang menghambat kesejahteraan rumah tangga. Krisis ekonomi tersebut juga menjadi permasalahan yang melanda negara-negara berkembang, sehingga banyak dampak yang dialami oleh warga negaranya, yakni terganggunya kegiatan produksi dan distribusi.

Kemiskinan yang banyak terjadi sekarang ini mempunyai penyebaran yang tidak seimbang baik antar wilayah yang ada di dunia ketiga maupun antara negara yang ada di wilayah-wilayah tersebut. Hampir setengah dari seluruh masyarakat hidup miskin. Beban kemiskinan paling besar terletak pada kelompok-kelompok tertentu. Kaum wanita pada umumnya merupakan pihak yang dirugikan, dalam 
rumah tangga miskin, mereka sering merupakan pihak yang menanggung beban kerja yang lebih berat dari pada kaum pria.

Masalah kemiskinan merupakan salah satu persoalan mendasar yang menjadi pusat perhatian pemerintah di negara manapun. Salah satu aspek penting untuk mendukung strategi penanggulangan kemiskinan adalah tersedianya data kemiskinan yang akurat dan tepat sasaran. Pengukuran kemiskinan yang dapat dipercaya dapat menjadi instrumen tangguh bagi pengambil kebijakan dalam memfokuskan perhatian pada kondisi hidup orang miskin. Data kemiskinan yang baik dapat digunakan untuk mengevaluasi kebijakan pemerintah terhadap kemiskinan, membandingkan kemiskinan antar waktu dan daerah, serta menentukan target penduduk miskin dengan tujuan untuk memperbaiki kondisi kemiskinan yang terjadi.

\section{TINJAUAN PUSTAKA \\ PENGERTIAN DESA}

Menurut Thomas (2013), desa dapat dipahami sebagai suatu daerah kesatuan hukum dimana bertempat tinggal di suatu masyarakat yang berkuasa (memiliki wewenang) mengadakan pemerintahan sendiri. Pengertian ini menekankan adanya otonomi untuk membangun tata kehidupan desa bagi kepentingan penduduk. Menurut Landis dalam Syachbrani (2012), desa adalah suatu wilayah yang jumlah penduduknya kurang dari 2.500 jiwa dengan ciri-ciri : pergaulan hidup yang saling kenalmengenal antar penduduk, pertalian perasaan yang sama tentang suatu kesukaan dan kebiasaan, kegiatan ekonomi yang pada umumnya agraris dan masih dipengaruhi oleh alam sekitar, seperti iklim dan keadaan serta kekayaan alam.

\section{PENGERTIAN ALOKASI DANA DESA}

Alokasi Dana Desa (ADD) adalah dana yang bersumber dari APBN yang diperuntukkan bagi desa yang ditransfer melalui APBD Kabupaten/Kota dan diprioritaskan untuk membiayai penyelenggaraan pemerintahan, pelaksanaan pembangunan, pembinaan kemasyarakatan dan pemberdayaan masyarakat desa. Penganggaran Dana Desa dalam APBN ditentukan 10\% dari dan di luar Dana Transfer Daerah secara bertahap (Peraturan Menteri Keuangan RI Nomor 241 Tahun 2014).

\section{ALOKASI DANA DESA UNTUK PEMBANGUNAN DESA}

Sumber daya manusia yang berkualitas dapat dicapai dengan adanya pengembangan sumber daya manusia melalui pembangunan. Pembangunan memiliki peran yang tinggi dan strategis dalam rangka meningkatkan sumber daya manusia. Bahkan lebih jauh lagi telah mampu meningkatkan pertumbuhan ekonomi baik bagi individu, masyarakat maupun pemerintah. Prioritas penggunaan dana desa untuk pembangunan desa dialokasikan untuk mencapai tujuan pembangunan desa yaitu meningkatkan kesejahteraan masyarakat desa dan kualitas hidup manusia serta penanggulangan kemiskinan, melalui: (Pasal 5 Peraturan Menteri Desa, Pembangunan Daerah Tertinggal, dan Transmigrasi Nomor 5 tahun 2015 tentang Penetapan Prioritas Penggunaan Dana Desa Tahun 2015). 


\section{ALOKASI DANA DESA UNTUK PEMBINAAN KEMASYARAKATAN DESA}

Pembinaan secara etimologi berasal dari kata bina. Pembinaan adalah proses, pembuatan, cara pembinaan, pembaharuan, usaha dan tindakan atau kegiatan yang dilakukan secara berdaya guna dan berhasil guna dengan baik. Menurut Tulusan (2014), pembinaan adalah segala hal usaha, ikhtiar dan kegiatan yang berhubungan dengan perencanaan dan pengorganisasian serta pengendalian segala sesuatu secara teratur dan terarah. Selanjutnya menurut Tanzeh (2009), pembinaan dapat diartikan sebagai bantuan dari seseorang atau sekelompok orang yang ditujukan kepada orang atau sekelompok orang lain melalui materi pembinaan dengan tujuan dapat mengembangkan kemampuan, sehingga tercapai apa yang diharapkan.

\section{ALOKASI DANA DESA UNTUK PEMBERDAYAAN MASYARAKAT}

Istilah pemberdayaan, dapat diartikan sebagai upaya memenuhi kebutuhan yang diinginkan oleh individu, kelompok dan masyarakat luas agar mereka memiliki kemampuan untuk melakukan pilihan dan mengontrol lingkungannya agar dapat memenuhi keinginan-keinginannya terhadap sumber daya yang terkait dengan pekejaannya, aktivitas sosialnya, dan lain-lain. Menurut Widjaja (2010), pemberdayaan adalah wewenang, pendelegasian wewenang atau pemberian otonomi kejajaran bawah. Selanjutnya menurut Mardikanto dan Soebianto (2013), Pemberdayaan masyarakat merupakan upaya untuk meningkatkan harkat dan martabat lapisan masyarakat yang dalam kondisi sekarang tidak mampu untuk melepaskan diri dari perangkap kemiskinan dan keterbelakangan.

\section{PRODUK DOMESTIK REGIONAL BRUTO}

Salah satu indikator penting untuk mengetahui kondisi ekonomi suatu daerah dalam suatu periode tertentu adalah data Produk Domestik Regional Bruto (PDRB), baik atas dasar harga berlaku maupun atas dasar harga konstan. Produk Domestik Regional Bruto (PDRB) didefinisikan sebagai jumlah nilai tambah yang dihasilkan oleh seluruh unit usaha dalam suatu wilayah atau merupakan jumlah nilai barang dan jasa akhir yang dihasilkan oleh seluruh unit ekonomi. Berdasarkan indikator ini kita akan memperoleh gambaran tingkat pertumbuhan ekonomi maupun tingkat kemakmuran masyarakat suatu wilayah. Menurut Sukirno (1985), pertumbuhan ekonomi diartikan sebagai kenaikan Gross Domestik Product tanpa memandang apakah kenaikan itu lebih besar atau lebih kecil dari tingkat pertumbuhan penduduk. Berbicara mengenai pertumbuhan ekonomi tidak terlepas dari pembangunan ekonomi itu sendiri sebab di dalam pertumbuhan ekonomi juga disertai dengan peningkatan kegiatan pembangunan yang mana tujuannya adalah untuk meningkatkan pendapatan perkapita yang tinggi.

\section{KEMISKINAN}

Kemiskinan merupakan masalah multidimensi karena berkaitan dengan ketidakmampuan akses secara ekonomi, sosial, budaya, politik dan partisipasi dalam masyarakat. Kemiskinan juga memiliki arti yang lebih luas dari sekedar lebih rendahnya tingkat pendapatan atau konsumsi seseorang dari standar kesejahteraan terukur seperti kebutuhan kalori minimum atau garis kemiskinan. Secara umum, kemiskinan adalah ketidakmampuan untuk mencapai standar atas aspek kehidupan, kemiskinan lebih 
terkait dengan ketidakmampuan untuk mencapai standar hidup tersebut daripada apakah standar hidup tersebut tercapai atau tidak (Siregar dan Wahyuniarti, 2008).

\section{KERANGKA KONSEPTUAL}

Kerangka konseptual yang digunakan sebagai dasar dalam penelitian ini adalah sebagai berikut:

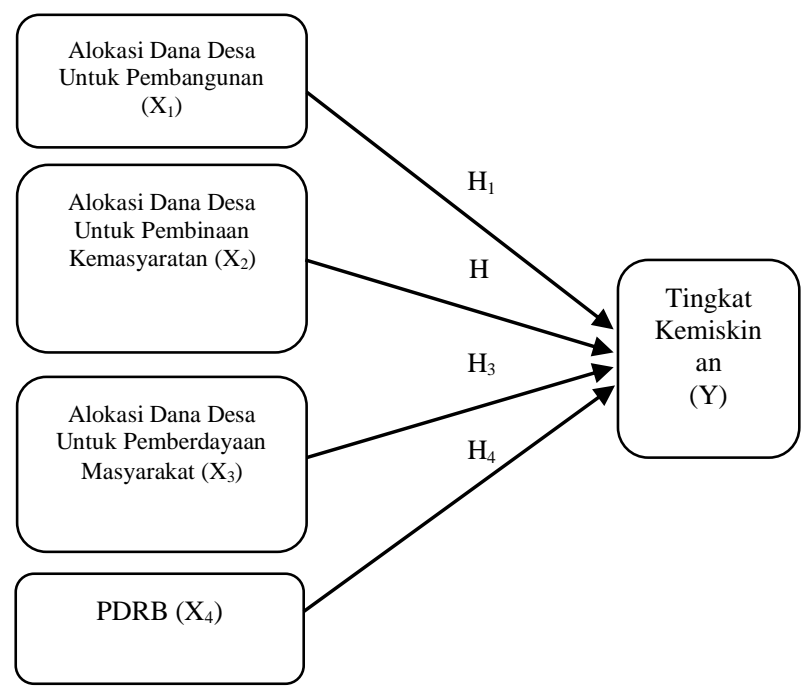

\section{HIPOTESIS}

Berdasarkan pengertian diatas maka peneliti dapat menyimpulkan bahwa hipotesis merupakan dugaan sementara terhadap masalah yang akan diuji, melalui analisis yang relevan dan hasilnya akan diketahui setelah dilakukan penelitian. Adapun hipotesis dalam penelitian ini adalah sebagai berikut:

$\mathrm{H}_{1}$ : Alokasi Dana Desa untuk Pembangunan Desa berpengaruh signifikan terhadap Penduduk Miskin Kabupaten/Kota di Provinsi Aceh.

$\mathrm{H}_{2}$ : Alokasi Dana Desa untuk Pembinaan Kemasyarakatan berpengaruh signifikan terhadap Penduduk Miskin Kabupaten/Kota di Provinsi Aceh.

$\mathrm{H}_{3}$ : Alokasi Dana Desa untuk Pemperdayaan Kemasyarakatan Desa berpengaruh signifikan terhadap Penduduk Miskin Kabupaten/Kota di Provinsi Aceh.

$\mathrm{H}_{4}$ : Diduga Produk Domestik Regional Bruto berpengaruh signifikan terhadap Penduduk Miskin Kabupaten/Kota di Provinsi Aceh.

\section{METODE PENELITIAN}

Objek penelitian adalah kemiskinan Kabupaten/Kota di Provinsi Aceh. Adapun variabel independen dalam penelitian ini adalah variabel Alokasi Dana Desa (ADD), variabel Kualitas Sumber Daya Manusia yang diwakili oleh variabel Alokasi Dana Desa untuk Pembangunan desa (ADPG), Alokasi Dana Desa untuk Pembinaan Kemasyarakatan desa (ADPB), Alokasi Dana Desa untuk Pemberdayaan Masyarakat desa (ADPD) dan Produk Domestik Regional Bruto (PDRB), sedangkan variabel dependennya adalah Kemiskinan (Penduduk miskin). Lokasi penelitian yaitu seluruh Kabupaten/Kota di Provinsi Aceh. Data penelitian adalah data sekunder berbentuk time series dan cross section dengan periode waktu selama 3 (tiga) tahun yaitu dari tahun 2015 sampai dengan tahun 2017. Menurut Supomo (2002), data sekunder umumnya berupa bukti, catatan atau laporan historis yang telah tersusun dalam 
arsip yang dipublikasikan dan yang tidak dipublikasikan.Data diperoleh dari Dinas Pemberdayaan Masyarakat dan Gampong (DPMG) Provinsi Aceh dan Badan Pusat Statistik (BPS) Provinsi Aceh dan studi pustaka.

\section{Definisi Operasional Variabel}

Untuk menguji hipotesis yang diajukan, variabel yang diteliti dalam penelitian ini diklasifikasikan menjadi variabel dependen dan variabel independen. Variabel independen dalam penelitian ini adalah Alokasi Dana Desa untuk Pembangunan (ADPG), Alokasi Dana Desa untuk Pembinaan Kemasyarakatan (ADPB), Alokasi Dana Desa untuk Pemberdayaan Masyarakat (ADPD) dan Produk Domestik Regional Bruto (PDRB). Sedangkan variabel dependennya adalah tingkat kemiskinan. Penelitian ini menggunakan pendekatan kuantitatif yang merupakan penelitian yang menekankan analisisnya pada data-data numerik dan diolah dengan metode statistika serta dilakukan pada penelitian inferensi atau dalam rangka pengujian hipotesis, sehingga diperoleh signifikansi antar variabel yang diteliti (Gujarati, 2012). Metode analisis data dalam penelitian ini adalah analisis regresi data panel. Data panel merupakan gabungan dari data cross section dan deret waktu (time series) yakni sejumlah variabel diobservasi atas sejumlah kategori dan dikumpulkan dalam suatu jangka waktu tertentu. Uji regresi panel ini digunakan untuk mengetahui hubungan antara variabel independen dengan variabel dependen. Pada penelitian ini data dioaleh dengan software Microsoft Excel dan pengolah data statistik Eviews 10, dengan model log linier sebagai berikut :

$$
y_{i t}=\beta_{0}+\beta_{1} \ln X_{1 i t}+\beta_{2} \ln X_{2 i t}+\beta_{3} \ln X_{3 i t}+\beta_{4} \ln X_{4 i t}+e_{i}
$$

Keterangan:

$$
\begin{array}{ll}
\mathrm{Y} & =\text { Variabel terikat } \\
I & =1,2,3,4 \ldots \mathrm{n} \\
T & =1,2,3,4 \ldots \mathrm{n} \\
\beta_{0} & =\text { Konstanta dari variabel bebas pada waktu } t \text { dan unit } i \\
\beta_{1 \ldots \beta_{5}} & =\text { Koefisien regresi/parameter } \\
X i t & =\text { Variabel bebas pada waktu } t \text { dan unit } i \\
E i & =\text { Error }
\end{array}
$$

Penggunaan data panel dalam sebuah observasi mempunyai beberapa keuntungan yang diperoleh. Pertama, data panel merupakan gabungan dua data time series dan cross section mampu menyediakan data yang lebih banyak sehingga akan menghasilkan degree of random yang lebih besar. Kedua, menggabungkan informasi dari data time series dan cross section dapat mengatasi masalah yang timbul ketika ada masalah penghilangan variabel (omitted-variable). 


\section{A. Uji Asumsi Klasik}

Pengujian asumsi klasik dilakukan terlebih dahulu sebelum pembentukan model regresi, supaya model regresi yang terbentuk menghasilkan estimasi yang memenuhi kriteria BLUE (Best Linear Unbiased Estimated), yang berati model regresi tidak mengandung masalah. Dengan demikian harus dilakukan pengujian terhadap 4 (empat) uji asumsi klasik yang meliputi uji normalitas, uji multikolinearitas, uji autokorelasi, dan uji heteroskedastisitas.

\section{Uji Normalitas}

Uji normalitas bertujuan untuk menguji apakah dalam model regresi, variabel pengganggu atau residual memiliki distribusi nomal. Dalam penelitian kali ini untuk menguji normalitas variable menggunakan Jarque-Bera test. Uji ini merupakan uji statistic untuk mengetahui data terdistribusi normal, dan untuk mengukur Jarque-Bera test dengan mencari perbedaan skewness dan kurtosis, Winarno (2007). Uji Jarque-Bera test distribusi dengan degree of freedom sebesar 2. Probablitas menunjukkan kemungkinan nilai Jarque-Bera melebihi nilai terobservasi dibawah hipotesis nol. Nilai Probabilitas yang kecil cenderung mengarahkan pada penolakan hipotesis nol data berdistribusi normal.

\section{Uji Multikolinearitas}

Uji multikoloniaritas dimaksudkan untuk mengetahui apakah terdapat interkorelasi yang sempurna diantara beberapa variabel bebas yang digunakan dalam persamaan regresi. Multikolinearitas adalah adanya hubungan antara variabel independen dalam satu persamaan regresi. Model regresi yang baik seharusnya tidak terjadi korelasi antara variabel independen. Multikolinearitas terindikasi apabila terdapat hubungan linier diantara variabel independen yang akan digunakan dalam model.

\section{Uji Autokorelasi}

Uji ini dilakukan untuk mengetahui tidak adanya korelasi diantara kesalahan pengganggu pada periode $t$ dengan kesalahan pada periode t-i (sebelumnya) dalam model regresi.Dalam regresi linier berganda, salah satu asumsi yang harus dipenuhi agar taksiran parameter dalam model tersebut bersifat Best Linear Unbiased Estimator (BLUE) adalah $\operatorname{cov}\left(u_{i}, u_{j}\right)=0 ; i \neq j$. Artinya, tidak ada korelasi antara $u_{i}$ dan $u_{j}$ untuk $\neq j\left\{E\left(u_{i}, u_{j}\right)=0, i \neq j\right\}$.

\section{Uji Heteroskedastisitas}

Uji heterosketastisitas bertujuan menguji apakah dalam model regresi terjadi ketidaksamaan varian dari residual satu pengamatan ke pengamatan yang lain. Jika varian dari residual satu pengamatan ke pengamatan lain tetap, maka disebut homoskedastisitas dan jika berbeda disebut heteroskedastisitas. 


\section{Analisis Data Panel}

Dalam panel data, data cross section yang sama diobservasi menurut waktu, Gujarati (2004). Panel data merupakan gabungan antara jenis data time series dan cross section sehingga panel data merupakan data yang memiliki dimensi waktu dan ruang. Nama lain panel data diantaranya : Pooled data, combination of time series dan cross section data, micropanel data, longitudinal data, event history analysis ataupun cohort analysis. Beberapa keuntungan dalam menggunakan data panel antara lain: Heteregonity, lebih informatif, bervariasi, degree of freedom lebih besar dan lebih efisien, menghindari masalah multikolinearitas, lebih unggul dalam mempelajari perubahan dinamis, lebih dapat mendeteksi dan mengukur pengaruh-pengaruh yang tidak dapat diobservasi pada data cross section murni atau time series murni, dapat digunakan untuk mempelajari behavioral model, dan meminimalisasi bias. Jika setiap cross unit memiliki jumlah obeservasi time series yang sama maka disebut sebagai balanced panel. Sebaliknya, jika jumlah observasi berbeda untuk setiap cross section unti disebut unbalanced panel.

Kesulitan yang mungkin ditemukan dalam mengestimasi data panel ialah dalam mengidentifikasi $t$ - rations atau $f$ - stat dari model regresinya yang dapat terjadi saat hanya seditkit jumlah observasi cross section dengan banyak data time series. Maka dapat dilakukan beberapa pendekatan dalam mengefiensikan perhitungan model regresi data panel. Pendekatan-pendekatan tersebut adalah (1) Metode Common-constant atau The Polled OLS method (2) Metode Fixed Effect atau Fixed Effect Model dan (3) Metode Random Effect atau Random Effect Model.

\section{Teknik Estimasi Regresi Data Panel}

Pada dasarnya ketiga teknik (model) estimasi data panel dapat dipilih sesuai dengan keadaan penelitian, dilihat dari jumlah individu bank dan variabel penelitiannya. Namun dimiakain, ada beberapa cara yang dapat digunakan untuk menentukan teknik mana yang paling tepat dalam mengestimasi parameter data panel. Menurut Widarjono (2007), uji statistik F dapat digunakan untuk memilih antara metode Common Effect atau metode Fixed Effect. Kedua, uji Hausman digunakan untuk memilih antara metode Fixed Effect atau metode Random Effect. Ketiga, uji Lagrange Multiplier (LM) digunakan untuk memilih antara metode common effect atau metode random effect.

Dalam software Eviews, metode random effct hanya dapat digunakan dalam kondisi jumlah individu bank lebih besar dibanding jumlah koefisien termasuk intersep. Selain itu, menurut beberapa ahli ekonometri dikatakan bahwa, jika data panel yang dimiliki mempunyai jumlah waktu (t) lebih besar dibandingkan jumlah individu (i), maka disarankan menggunakan metode Fixed Effect. Sedangkan jika data panel yang dimiliki mempunyai jumlah waktu (t) lebih kecil dibandingkan jumlah individu (i), maka disarankan menggunakan metode Random Effect. 


\section{Pengujian Hipotesis}

Menurut Nachrowi (2006), uji hipotesis berguna untuk menguji signifikasi koefisien regersi yang didapat.

\section{Uji secara Parsial (Uji-t )}

Menurut Gujarati dan Porter (2013), uji signifikansi merupakan sebuah prosedur yang digunakan untuk menguji kebenaran atau kesalahan dari hasil hipotesis nol dari sampel. Ide dasar pengujian signifikansi dilator belakangi oleh uji statistik (estimator) dari dstribusi sampel dari suatu statistic di bawah hipotesis nol. Keputusan untuk $\mathrm{H}_{0}$ diterima atau ditolak dibuat berdasarkan nilai uji statistik yang diperoleh dari data yang telah ada. Dalam uji signifikansi, sebuah statistik dikatakan signifikan secara statistik apabila nilai dari uji statistiknya berada di daerah tolak, sebaliknya, sebuah pengujian dikatakan tidak signifikan secara statistik, jika nilai dari uji statistiknya berada di daerah penerimaan.

Hipotesis :

1. Ho diterima jika $\mathrm{t}$ hitung $<\mathrm{t}$ tabel, artinya tidak ada pengaruh signifikan antara variabel independen terhadap variabel dependen.

2. $\mathrm{H}_{1}$ diterima jika $\mathrm{t}$ hitung $>\mathrm{t}$ tabel, artinya ada pengaruh secara signifikan variabel independen terhadap variabel dependen.

\section{Uji Secara Bersama-sama (Uji F)}

Uji $\mathrm{F}$ digunakan untuk mengetahui pengaruh variabel independen secara bersama-sama (simultan) terhadap variabel dependen. Signifikan berarti hubungan yang terjadi dapat berlaku untuk populasi. Penggunaan tingkat signifikansinya beragam, tergantung keputusan peneliti, yaitu 0,01 (1\%); 0,05 (5\%) dan 0,10 (10\%). Dalam uji F-statistik, langkah-langkah yang perlu dilakukan adalah, Gujarati dan Porter (2012).

\section{Hipotesis :}

1. $\quad \mathrm{F}$ hitung $>\mathrm{F}$ tabel maka $\mathrm{H}_{0}$ ditolak dan $\mathrm{H}_{1}$ diterima, artinya semua variabel independen secara bersama-sama berpengaruh secara signifikan terhadap variabel dependen.

2. $\mathrm{F}$ hitung $<\mathrm{F}$ tabel maka $\mathrm{H}_{0}$ diterima dan $\mathrm{H}_{1}$ ditolak, artinya semua variabel independen secara bersama-sama tidak berpengaruh secara signifikan terhadap variabel dependen.

\section{Koefisien Determinasi $\left(\mathbf{R}^{2}\right)$}

Koefisien Deteminasi (Goodness of Fit) dinotasikan dengan $R$-square yang merupakan suatu ukuran yang penting dalam regersi, karena dapat menginformasikan baik atau tidaknya model regresi yang terestimasi.

\section{Koefisien Korelasi (R)}

Koefesien korelasi ialah pengukuran statistik kovarian atau asosiasi antara dua variabel. Besarnya koefesien korelasi berkisar antara +1 s/d -1 . Koefesien korelasi menunjukkan kekuatan (strength) hubungan linear dan arah hubungan dua variabel acak. 


\section{HASIL PENELITIAN}

\section{Uji Asumsi Klasik}

Pengujian asumsi klasik dilakukan terlebih dahulu sebelum pembentukan model regresi, supaya model regresi yang terbentuk menghasilkan estimasi yang memenuhi kriteria BLUE (Best Linear Unbiased Estimated), yang berati model regresi tidak mengandung masalah.

\section{Uji normalitas}

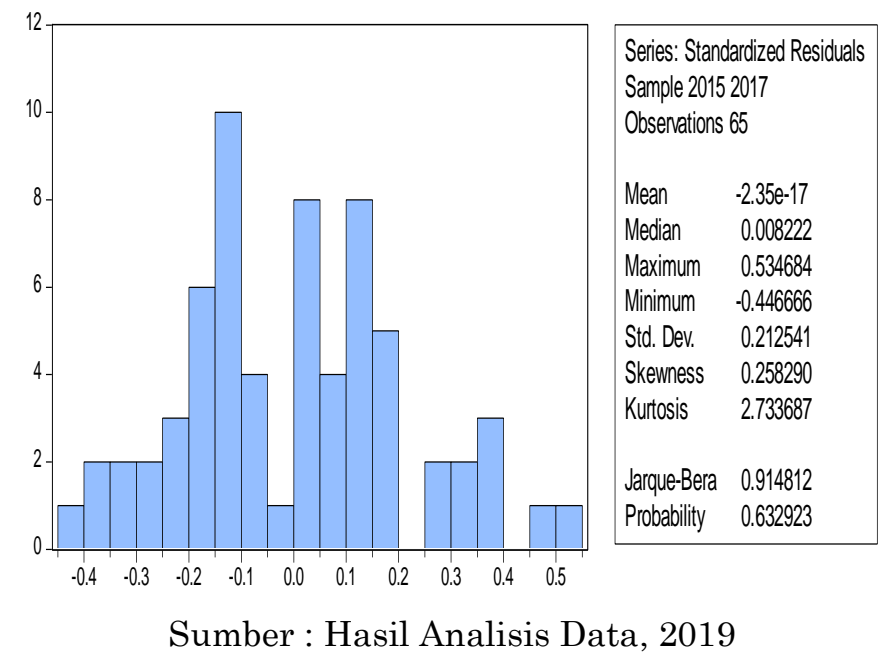

Berdasarkan Gambar di atas, hasil pengujian normalitas menunjukkan bahwa nilai probabilitas lebih besar dari 0,05 atau 0,91>0,05. Jadi, dapat disimpulkan residual dalam model yang diuji terbukti berdistribusi normal.

\section{Uji Multikolinearitas}

Uji multikolinearitas dilakukan untuk mengamati ada tidaknya korelasi yang signifikan antara variabel bebas dalam suatu model regresi. Jika ada korelasi yang tinggi di antara variabel-variabel bebasnya, maka korelasi antara variabel bebas terhadap variabel terikatnya akan menjadi terganggu. Untuk menguji masalah multikolinearitas dapat dilakukan dengan melihat matriks korelasi dari variabel bebas, jika koefiensi korelasi lebih dari 0,80 maka dapat disimpulkan terdapat multikolinearitas, Gujarati dan Porter (2009). 


\begin{tabular}{|c|c|c|c|c|}
\hline \multicolumn{5}{|c|}{ Covariance Analysis: Ordinary } \\
\hline \multicolumn{5}{|c|}{ Included observations: } \\
\hline \multicolumn{5}{|l|}{65} \\
\hline \multirow{3}{*}{$\begin{array}{l}\text { Balanced } \\
\text { deletion) }\end{array}$} & sample $\quad(1$ & twise & value & \\
\hline & LNADPG & LNADPB & LNADPD & LNPDR \\
\hline & & & & B \\
\hline LNADPG & 1.000000 & 0.445197 & 0.717479 & 0.569910 \\
\hline LNADPB & 0.445197 & 1.000000 & 0.449335 & 0.338953 \\
\hline LNADPD & 0.717479 & 0.449335 & 1.000000 & 0.279457 \\
\hline LNPDRB & 0.569910 & 0.338953 & 0.279457 & 1.000000 \\
\hline
\end{tabular}

Sumber : Hasil Analisis Data, 2019

Berdasarkan output di atas, tidak ada variabel yang memiliki nilai lebih dari 0,8. Maka dapat disimpulkan bahwa tidak terjadi multikolinearitas pada model regresi ini, sehingga dapat disimpulkan bahwa model penelitian ini terbebas dari multikolinearitas.

\section{Uji Heterokedastisitas}

\begin{tabular}{|c|c|c|c|}
\hline Variable & Coefficient Std. Error & t-Statistic & Prob. \\
\hline $\mathrm{C}$ & $-2.768170 \quad 6.874119$ & -0.402695 & 0.6894 \\
\hline LNADPG & $-0.028674 \quad 0.041780$ & -0.686316 & 0.4967 \\
\hline LNADPB & $-0.026288 \quad 0.015953$ & -1.647813 & 0.1076 \\
\hline LNADPD & $-0.031078 \quad 0.023822$ & -1.304621 & 0.1999 \\
\hline LNPDRB & $0.323389 \quad 0.475648$ & 0.679892 & 0.5007 \\
\hline
\end{tabular}

Sumber : Hasil Analisis Data, 2019

Berdasarkan Tabel di atas, hasil pengujian heteroskedastisitas dengan menggunakan uji Glesjer, didapatkan nilai probabilitas variabel independent variabel Alokasi Dana Desa untuk Pembangunan (ADPG), Alokasi Dana Desa untuk Pembinaan Kemasyarakatan (ADPB), Alokasi Dana Desa untuk Pemberdayaan Masyarakat (ADPD) dan Produk Domestik Regional Bruto (PDRB) keseluruhannya di atas 0,05 yang artinya variabel independen pada penelitian ini tidak ada indikasi heteroskedastisitas. 


\section{Uji Autokorelasi}

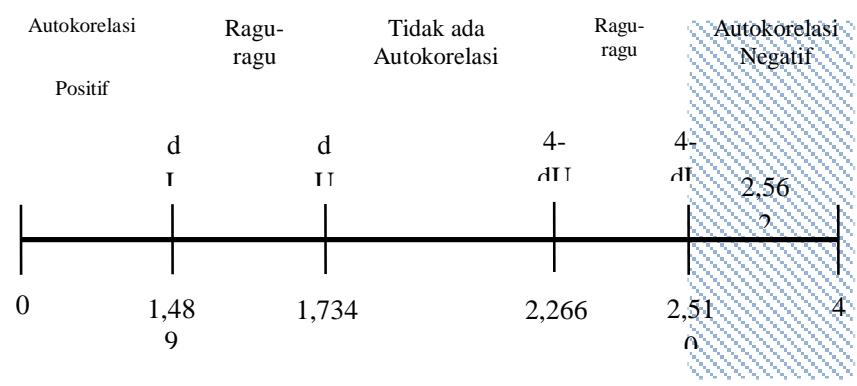

Jumlah sampel sebanyak 69 observasi $(\mathrm{n}=69)$ dan total variabel independen sebanyak empat $(\mathrm{k}=$ 4), maka diperoleh nilai dL dan dU pada tabel Durbin Watson dengan alpha 5\%yaitu sebesar 1,489 dan 1,734. Syarat model terbebas dari autokorelasi jika nilai Durbin Watson yang diperoleh berkisar antara dU dengan 4-dU. Adapun 4-dU yang diperoleh yaitu sebesar 2,266 dengan angka Durbin Watson yang diperoleh dari tabel di atas sebesar 2,562. Hal ini menunjukkan bahwa adanya indikasi autokorelasi negatif pada model dengan nilai Durbin Watson lebih besar dibandingkan 4-dL atau 2,562 >2,510.

\section{Uji Chow (ChowTest):}

\begin{tabular}{lccc}
\hline Effects Test & Statistic & d.f. & Prob. \\
\hline \hline $\begin{array}{l}\text { Cross-section F } \\
\text { Cross-section Chi- }\end{array}$ & & & 0.0000 \\
square & 344.5715594 & $(22,38)$ & \\
\hline
\end{tabular}

Berdasarkan Tabel hasil redundant fixed effect atau like lihood ratio untuk model ini memiliki nilai probabilitas $0,000<$ dari a $(0,05)$, sehingga $\mathrm{H}_{0}$ ditolak dan $\mathrm{H}_{1}$ diterima, model yang sesuai dari hasil ini yaitu fixed effect model, karena nilai probabilitas sebesar $0,000<0,05$. Dengan demikian, maka model yang pilih adalah fixed effect model. Berdasarkan hasil ini model bisa dilanjutkan ke Random Effect Model.

\begin{tabular}{cccc}
\hline \hline Test Summary & $\begin{array}{c}\text { Chi-Sq. } \\
\text { Statistic }\end{array}$ & Chi-Sq. d.f. & Prob. \\
\hline \hline Cross-section random & 14.799226 & 4 & 0.0051 \\
\hline
\end{tabular}

Berdasarkan Tabel 5.5 diperoleh nilai Prob (p-value) adalah sebesar 0,0051< dari taraf signifikansi a $(0,05$ atau $5 \%)$, maka menolak hipotesis nol dan menerima $\mathrm{H}_{1}$, sehingga dapat disimpulkan model yang terpilih adalah Fixed effect model 


\section{Hasil Pengolahan Data Model Regresi Panel}

Pembahasan pada bab ini dimulai dengan regresi data panel dalam beberapa tahap diantaranya yang pertama dengan melihat model Pool Least Square (PLS) atau Common Effect, Fixed Effect Model (FEM) dan Random Effect Model (REM). Berikut ini adalah tahapan pengolahan dan modelnya :

\section{Model Pooled Least Squares (PLS) atau Common Effect}

\begin{tabular}{crrrr}
\hline \hline & \multicolumn{4}{c}{ Std. } \\
Variable & Coefficient & Error & t-Statistic & Prob. \\
\hline \hline C & 23.63567 & 9.720466 & 2.431537 & 0.0180 \\
LNADPG & 1.921237 & 0.594869 & 3.229683 & 0.0020 \\
LNADPB & 0.522947 & 0.308576 & 1.694709 & 0.0953 \\
LNADPD & -0.260508 & 0.494681 & -0.526618 & 0.6004 \\
LNPDRB & -3.906604 & 0.657813 & -5.938772 & 0.0000 \\
\hline \hline
\end{tabular}

Berdasarkan hasil pengolahan data pada Tabel 5.6 terlihat bahwa variabel Alokasi Dana Desa untuk pembinaan masyarakat (ADPB) dan Alokasi Dana Desa untuk Pemberdayaan Masyarakat desa (ADPD) tidak berpengaruh terhadap Tingkat Kemiskinan, namun karena model ini tidak sesuai dengan hasil pengujian kesesuaian model, maka dilanjutkan dengan melalukan pengolahan data untuk fixed effect model.

\section{Fixed Effect Model (FEM)}

Tabel 5.7

\section{Hasil Regresi Fixed Effect Model}

\begin{tabular}{crrrr}
\hline \hline Variable & \multicolumn{2}{c}{ Coefficient Std. Errort-Statistic } & Prob. \\
\hline \hline C & 32.11379 & 16.81071 & 1.910317 & 0.0637 \\
LNADPG & -0.234655 & $0.102174-2.296626$ & 0.0272 \\
LNADPB & -0.073742 & $0.039014-1.890160$ & 0.0664 \\
LNADPD & -0.006768 & $0.058256-0.116176$ & 0.9081 \\
LNPDRB & -0.486049 & $1.163201-0.417855$ & 0.6784 \\
\hline \hline
\end{tabular}

Dari hasil pengolahan data pada Tabel diperoleh hasil penelitian dengan model awal adalah :

$$
T M_{i t}=\beta_{0}+\beta_{1} \ln A D P G_{2 i t}+\beta_{2} \ln A D P B_{3 i t}+\beta_{3} \ln A D P D_{4 i t}+\beta_{4} \ln P D R B_{5 i t}+e_{i t}
$$

$\mathrm{TM}_{\mathrm{it}}=32,114+-0,235 \ln \mathrm{ADPG}_{2 \mathrm{it}}+-0,007 \ln \mathrm{ADPB}_{3 \mathrm{it}}+-0,007 \ln \mathrm{ADPD}_{4 \mathrm{it}}+-0,486 \ln \mathrm{PDRB}_{5 \mathrm{it}}+\mathrm{e}_{\mathrm{it}}$

Berdasarkan persamaan linier tersebut dapat dijelaskan bahwa : Konstanta $\left(\beta_{0}\right),=32,114$. Artinya jika nilai variabel independen ADPG, ADPB, ADPD, dan PDRB dianggap konstan atau tidak berubah, 
maka tingkat kemiskinan yang ada di Kabupaten/Kota Provinsi Aceh juga bernilai konstan 32,114 atau $32,11 \%$.

Variabel Alokasi Dana Desa untuk Pembangunan desa (ADPG) sebesar -0,235 menunjukkan apabila Alokasi Dana Desa untuk Pembangunan desa (ADPG) meningkat sebesar 1 persen, maka akan menurunkan Tingkat Kemiskinan sebesar 23,5\% dengan asumsi Alokasi Dana Desa untuk Pembinaan Kemasyarakatan desa (ADPB), Alokasi Dana Desa untuk Pemberdayaan masyarakat desa (ADPD) dan Produk Domestik Regional Bruto (PDRB) bernilai konstan.

Variabel Alokasi Dana Desa untuk Pembinaan Kemasyarakatan desa (ADPB) sebesar -0,007 menunjukkan apabila Alokasi Dana Desa untuk Pembinaan Kemasyarakatan desa (ADPB) meningkat sebesar 1 persen, maka akan menurunkan tingkat kemiskinan sebesar 0,007 persen dengan asumsi Alokasi Dana Desa untuk Pembinaan Kemasyarakatan desa (ADPB), Alokasi Dana Desa untuk Pemberdayaan masyarakat desa (ADPD) dan Produk Domestik Regional Bruto (PDRB) bernilai konstan.

Variabel Alokasi Dana Desa untuk Pemberdayaan masyarakat desa (ADPD) sebesar -0,007 menunjukkan apabila Alokasi Dana Desa untuk Pemberdayaan masyarakat desa (ADPD) meningkat sebesar 1 persen, maka akan menurunkan tingkat kemiskinan sebesar -0,007 persen dengan asumsi variabel Alokasi Dana Desa untuk Pembinaan Kemasyarakatan desa (ADPB), Alokasi Dana Desa untuk Pemberdayaan masyarakat desa (ADPD) dan Produk Domestik Regional Bruto (PDRB) bernilai konstan.

Variabel Produk Domestik Regional Bruto (PDRB) sebesar -0,486 menunjukkan apabila Produk Domestik Regional Bruto (PDRB) meningkat sebesar 1 persen, maka akan menurunkan Tingkat Kemiskinan sebesar 0,486 persen dengan asumsi variabel Alokasi Dana Desa (ADD), Alokasi Dana Desa untuk Pembinaan Kemasyarakatan desa (ADPB), dan Alokasi Dana Desa untuk Pemberdayaan Masyarakat desa (ADPD) bernilai konstan.

\section{Hasil Pengujian Secara Parsial (Uji-t)}

\begin{tabular}{|c|c|c|c|}
\hline & Coefficien & & \\
\hline Variable & t Std. Error & t-Statistic & Prob. \\
\hline $\mathrm{C}$ & $32.11379 \quad 16.81071$ & 1.910317 & 0.0637 \\
\hline LNADPG & $-0.234655 \quad 0.102174$ & -2.296626 & 0.0272 \\
\hline LNADPB & $-0.073742 \quad 0.039014$ & -1.890160 & 0.0664 \\
\hline LNADPD & $-0.006768 \quad 0.058256$ & -0.116176 & 0.9081 \\
\hline LNPDRB & $-0.486049 \quad 1.163201$ & -0.417855 & 0.6784 \\
\hline
\end{tabular}

Hasil penelitian menunjukan thitung variabel ADPG bernilai -2,297 hasil penelitian ini menunjukan menerima $\mathrm{H}_{1}$ dilihat dari nilai $t_{\text {hitung }}>\mathrm{t}_{\text {tabel }}(2,297>1,669)$ dan nilai probabiltas $(0,027<0,05)$ yang artinya Alokasi Dana Desa untuk Pembangunan (ADPG) memiliki pengaruh yang negatif dan signifikan terhadap tingkat kemiskinan. 
Hasil penelitian menunjukan thitung variabel ADPB sebesar -1.890, hasil penelitian ini menunjukan menerima $\mathrm{H}_{2}$ berdasarkan dari nilai $t_{\text {hitung }}>\mathrm{t}_{\text {tabel }}(1.890>1,295)$ dan nilai probabiltas $(0,066<0,10)$ yang artinya Alokasi Dana Desa untuk Pembinaan Kemasyarakatan (ADPB) memiliki pengaruh yang negatif dan signifikan terhadap tingkat kemiskinan.

Hasil penelitian menunjukan thitung Variabel ADPD sebesar -0.116, hasil penelitian ini menunjukan menolak $\mathrm{H}_{3}$ dilihat dari nilai thitung $<\mathrm{t}_{\text {tabel }}(0.116<1,669)$ dan nilai probabiltas $(0.908>0,05)$ yang artinya Alokasi Dana Desa untuk Pemberdayaan masyarakat desa (ADPD) tidak memiliki pengaruh dan tidak signifikan terhadap tingkat kemiskinan.

Hasil penelitian menunjukan thitung Variabel PDRB sebesar -0,418, hasil penelitian ini menunjukan menolak $\mathrm{H}_{4}$ dilihat dari nilai thitung $<\mathrm{t}_{\text {tabel }}(0,418,<1,669)$ dan nilai probabiltas $(0,678>0,05)$ yang artinya Produk Domestik Regional Bruto tidak memiliki pengaruh dan tidak signifikan terhadap tingkat kemiskinan.

\section{Hasil Pengujian Secara Serentak (Uji F)}

\begin{tabular}{llc}
\hline \hline & \multicolumn{2}{c}{ Hannan-Quinn } \\
Log likelihood & \begin{tabular}{c} 
8.933146criter. \\
\multicolumn{1}{c}{ Durbin-Watson }
\end{tabular} \\
& \multicolumn{2}{c}{0.912276} \\
F-statistic & 485.7400 stat & 2.561996 \\
Prob(F-statistic) & 0.000000 & \\
\hline \hline
\end{tabular}

Berdasarkan Tabel 5.9 didapatkan $\mathrm{F}_{\text {hitung }}>\mathrm{F}_{\text {tabel }}(485,740>2,52)$ dan nilai signifikansi $(0,000<$ 0,05) yang dapat disimpulkan bahwa Alokasi Dana Desa untuk Pembangunan (ADPG), Alokasi Dana Desa untuk Pembinaan Kemasyarakatan (ADPB), Alokasi Dana Desa untuk Pemberdayaan masyarakat desa (ADPD) dan Produk Domestik Regional Bruto (PDRB) secara bersama-sama berpengaruh simultan terhadap tingkat kemiskinan Kabupaten/Kota di Provinsi Aceh.

\section{Koefisien Determinan $\left(R^{2}\right)$ dan Korelasi $(R)$}

Analisis korelasi bertujuan untuk mengukur kekuatan asosiasi (hubungan) linear antara dua variabel. Korelasi tidak menunjukkan hubungan fungsional atau dengan kata lain, analisis korelasi tidak membedakan antara variabel dependen dengan variabel independen.

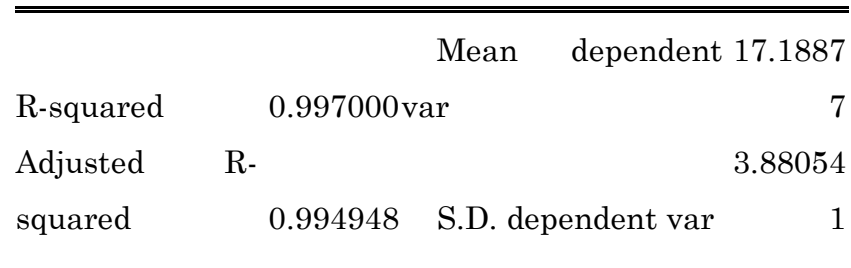

Koefisien determinasi Adjusted R-square sebesar 0,994 atau (99,4\%), artinya Alokasi Dana Desa untuk Pembangunan (ADPG), Alokasi Dana Desa untuk Pembinaan Kemasyarakatan (ADPB), Alokasi 
Dana Desa untuk Pemberdayaan Masyarakat desa (ADPD) dan Produk Domestik Regional Bruto (PDRB) memiliki pengaruh terhadap tingkat kemiskinan di Kabupaten/Kota Provinsi Aceh sebesar 0,994 atau $99,4 \%$. Sedangkan sisanya $(0,06 \%)$ dipengaruhi oleh variabel lain diluar model yang tidak dimasukkan dalam penelitian ini.

\section{Koefisien Korelasi (R)}

Koefesien korelasi ialah pengukuran statistik kovarian atau asosiasi antara dua variabel. Besarnya koefesien korelasi berkisar antara +1 s/d -1 . Koefesien korelasi menunjukkan kekuatan (strength) hubungan linear dan arah hubungan dua variabel acak. Jika koefesien korelasi positif, maka kedua variabel mempunyai hubungan searah. Artinya jika nilai variabel X tinggi, maka nilai variabel Y akan tinggi pula. Sebaliknya, jika koefesien korelasi negatif, maka kedua variabel mempunyai hubungan terbalik. Artinya jika nilai variabel $\mathrm{X}$ tinggi, maka nilai variabel $\mathrm{Y}$ akan menjadi rendah (dan sebaliknya). Untuk memudahkan melakukan interpretasi mengenai kekuatan hubungan antara dua variabel penulis memberikan kriteria sebagai berikut, Sarwono (2006):

○ $\quad 0$ : Tidak ada korelasi antara dua variabel

$\circ \quad>0-0,25:$ Korelasi sangat lemah

○ $\quad>0,25-0,5:$ Korelasi cukup

$\circ>0,5-0,75:$ Korelasi kuat

○ $>0,75-0,99$ : Korelasi sangat kuat

○ 1: Korelasi sempurna

Berdasarkan hasil pengolahan data pada Tabel 5.8 dapat dilihat koefisien korelasi $\left(\mathrm{R}^{2}\right)$ sebesar sebesar 0.997 atau 99,7\%, artinya Alokasi Dana Desa untuk Pembangunan (ADPG), Alokasi Dana Desa untuk Pembinaan Kemasyarakatan (ADPB), Alokasi Dana Desa untuk Pemberdayaan Masyarakat desa (ADPD) dan Produk Domestik Regional Bruto (PDRB) memiliki hubungan korelasi yang sangat kuat secara positif terhadap tingkat kemiskinan Kabupaten/Kota di Provinsi Aceh, karena nilai korelasi sebesar 0,997 mendekati positif satu (+1

\section{IMPLIKASI}

Penelitian ini menghasilkan beberapa implikasi secara teoritis yaitu sebagai berikut:

1. Hasil penelitian ini juga menunjukkan bahwa variabel Alokasi Dana Desa untuk Pembangunan (ADPG) dan Alokasi Dana Desa untuk Pembinaan Kemasyarakatan desa (ADPB) memiliki arah pengaruh yang negatif dan signifikan terhadap tingkat kemiskinan. Kondisi ini menjelaskan bahwa Alokasi Dana Desa untuk Pembangunan desa (ADPG) dan Alokasi Dana Desa untuk Pembinaan Kemasyarakatan (ADPB) dalam menuntaskan kemiskinan sudah baik, namun perlu adanya reformasi yang lebih fokus terhadap pembinaan SDM yang ada di desa-desa di Kabupaten/Kota Provinsi aceh agar masyarakat mampu meningkatkan potensi diri sehingga dapat membuka peluang terciptanya lapangan usaha. Pendapat tersebut juga sejalan dengan teori menurut Bempah (2013), penggunaan dana yang dialokasikan untuk setiap desa ditujukan untuk pembangunan segala 
infrastruktur yang dianggap dapat mendorong perekonomian pedesaan. Dengan demikian dapat mengurangi kemiskinan di daerah pedesaan.

2. Hasil penelitian dapat memberi kontribusi yang berharga bagi ilmu pengetahuan Karena dapat menambah penelitian sebelumnya yang masih dirasakan belum tersedia banyak, berhubungan dengan kedudukan variabel Alokasi Dana Desa untuk Pembangunan desa, Alokasi Dana Desa untuk Pembinaan Kemasyarakatan desa, Alokasi Dana Desa untuk Pemberdayaan Masyarakat desa dan Produk Domestik Regional Bruto dan Kemiskinan.

Implikasi secara praktisbeberapa saran alternatif yang bersifat strategis untuk pemerintah Kabupaten/Kota di Provinsi Aceh.

1. Hasil penelitian ini menunjukkan bahwa variabel Alokasi Dana Desa untuk Pembangunan desa dan Alokasi Dana Desa untuk Pembinaan memiliki arah pengaruh yang signifikan terhadap Tingkat Kemiskinan di Kabupaten/Kota Provinsi Aceh, dengan kata lain variabel Alokasi Dana Desa untuk Pembangunan desa dan Alokasi Dana Desa untuk Pembinaan Kemasyarakatan desa berdampak pada penurunan kemiskinan di Kabupaten/Kota Provinsi Aceh. Temuan ini mengisyaratkan bahwa Pemerintah lebih mengoptimalkan dalam pengguanaan anggaran.

2. Hasil penelitian ini menunjukkan bahwa variabel Alokasi Dana Desa Pembangunan desa, Alokasi Dana Desa untuk Pemberdayaan masyarakat desa dan Produk Domestik Regional Bruto memiliki arah pengaruh positif namun tidak signifikan terhadap tingkat kemiskinan di Kabupaten/Kota Provinsi Aceh. Maka dari itu pemerintah harus mampu mengoptimal variabel yang tidak signifikan terhadap penurunan angka kemiskinan agar upaya mensejahterakan masyarakat dapat terwujud.

\section{SIMPULAN}

Berdasarkan hasil penelitian serta pembahasan yang telah diuraikan sebelumnya, maka dapat disampaikan beberapa kesimpulan sebagai berikut:

1. Hasil penelitian menunjukan variabel Alokasi Dana Desa untuk Pembangunan desa berpengaruh negatif terhadap tingkat kemiskinan Kabupaten/Kota di Provinsi Aceh. Kondisi ini menjelaskan bahwa Alokasi Dana Desa untuk Pembangunan memberikan pengaruh negatif yang artinya Alokasi Dana Desa untuk Pembangunan desa di Kabupaten/Kota Provinsi Aceh mampu menurunkan tingkat kemiskinan.

2. Hasil penelitian menunjukan variabel Alokasi Dana Desa untuk Pembinaan desa berpengaruh negatif terhadap tingkat kemiskinan Kabupaten/Kota di Provinsi Aceh. Kondisi ini menjelaskan bahwa Alokasi Dana Desa untuk Pembinaan Kemasyarakatan dalam menuntaskan kemiskinan sudah berjalan semestinya namun diperlukan perbaikan secara terus menerus.

3. Hasil penelitian menunjukan variabel Alokasi Dana Desa untuk Pemberdayaan masyarakat desa tidak berpengaruh terhadap tingkat kemiskinan Kabupaten/Kota di Provinsi Aceh. Kondisi ini menjelaskan bahwa belum optimalnya kinerja perangkat desa dalam menjalankan Peraturan Pemerintah Republik Indonesia Nomor 43 Tahun 2014, disebutkan bahwa Kepala Desa mempunyai tugas nyelenggarakan urusan pemerintahan, pembangunan, dan kemasyarakatan. 
4. Hasil penelitian menunjukan variabel Produk Domestik Regional Bruto tidak berpengaruh signifikan terhadap Tingkat Kemiskinan Kabupaten/Kota di Provinsi Aceh. Kemiskinan merupakan masalah kompleks yang dihadapi di setiap daerah yang ada di Indonesia tak terkecuali Provinsi Aceh. Hal ini disebabkan rendahnya tingkat pendidkan, kesehatan serta ketidakberdayaan untuk berpartisipasi dalam pembangunan serta berbagai masalah yang berkenaan dengan pembangunan manusia sehingga memberikan dampak terhadap lesuhnya perekonomian provinsi Aceh.

\section{SARAN}

Dalam rangka mengatasi tingkat kemiskinan di Kabupaten/Kota Provinsi Aceh, maka penulis menyarankan beberapa saran sebagai berikut:

1. Kondisi kemiskinan di seluruh Aceh harus menjadi pekerjaan rumah bersama antara Pemerintah Aceh dengan seluruh Pemerintah Kabupaten/Kota di Provinsi Aceh agar penyusunan RKA APBA maupun APBK berjalan sesuai tujuan, maka harus ada Master Plan yang jelas mengenai kebijakan riil dari alokasi anggaran yang bersentuhan langsung dengan masyarakat, terutama untuk menurunkan angka kemiskinan di Aceh. Selain itu, diharapkan masyarakat turut serta untuk mengawal kinerja dan tata kelola pemerintahan, terutama mengawal kebijakan tata kelola APBA dan APBK supaya tepat sasaran dan dapat meminimalisir terjadinya penyimpangan atau praktik korupsi. Hal ini perlu diawasi penggunaannya oleh aparat pemerintahan desa agar penyaluran bisa berjalan secara maksimal dan efisien.

2. Pengalokasian Dana Desa yang dilakukan oleh aparatur desa masih jauh dari kebutuhan dan keinginan masyarakat desa dan belum sesuai dengan Permendes Nomor 5 Tahun 2015. Oleh karena itu, diharapkan Pemerintah Kabupaten/Kota di Provinsi Aceh dapat mengawasi dan memperhatikan setiap penggunaan Dana Desa dengan tepat waktu dalam memberikan sosialisasi dan meningkatkan pengawasan terhadap pengeluaran-pengeluaran Alokasi Dana Desa yang dilakukan oleh Kepala Desa. Selanjutnya diharapkan untuk Kepala Desa di Kabupaten/Kota Provinsi Aceh agar dalam penggunaan Dana Desa dilakukan sesuai dengan peraturan perundang-undangan Republik Indonesia yang berlaku sehingga penggunaannya akan tepat sasaran, dengan demikian manfaat dari Alokasi Dana Desa tersebut dapat dirasakan oleh masyarakat desa dan tujuan dari Program Alokasi Dana Desa dalam menekan angka kemiskinan dapat tercapai.

3. Penulis menyarankan pengunaan Alokasi Dana Desa tidak hanya berfokus pada pembangunan infrastuktur semata. Karena pengembangan kualitas sumber daya manusia harus juga mendapatkan porsi yang sama seperti Alokasi Dana Desa untuk infrastuktur, sehingga dengan majunya infrastruktur akan sejalan dengan peningkatan kualitas sumber daya manusia yang baik.

4. Selanjutnya yang harus dilakukan oleh pihak terkait adalah melakukan rekonsiliasi terhadap pertumbuhan ekonomi, karena pertumbuhan ekonomi merupakan indikator untuk melihat keberhasilan pembangunan dan merupakan syarat bagi pengurangan tingkat kemiskinan. Syaratnya adalah hasil dari pertumbuhan ekonomi tersebut menyebar ke setiap golongan masyarakat, termasuk digolongan masyarakat miskin.

5. Selanjutnya guna mencegah perekonomian yang lesu, ada beberapa langkah yang disarankan kepada pemerintah yaitu: Pertama, penguatan sektor pertanian dan perkebunan karena sebagian 
masyarakat Aceh bermata pencarian sebagai petani. Karena itu, pemerintah daerah perlu memprioritaskan sektor pertanian dan perkebunan dengan menghidupkan kembali Koperasi Unit Desa (KUD) yang dikelola secara profesional bekerja sama dengan pihak swasta.

\section{KETERBATASAN PENELITIAN}

Adapun keterbatasan dalam penelitian ini adalah sebagai berikut :

1. Penelitian ini hanya menggunakan empat variabel bebas dan satu variabel terikat. Bagi peneliti berikutnya yang ingin meneliti lebih lanjut tentang permasalahan ini supaya dapat menambah lebih banyak lagi variabel lain yang dirasa sesuai dengan keadaan atau fenomena yang berkaitan dengan tingkat kemiskinan Kabupaten/Kota di Provinsi Aceh.

2. Program Alokasi Dana Desa baru berjalan 3 (tiga) tahun, yaitu baru dilaksanakan pada tahun 2015 sehingga multiplier effect belum terlihat.

3. Data yang dikaji dalam penelitian ini relatif sedikit, sehingga perlu kajian lanjutan dengan menambahkan data atau variabel lainnya. Selain data Alokasi Dana Desa juga dapat ditambahkan dengan variabel-variabel lain yang mendukung dalam menurunkan jumlah tingkat kemiskinan seperti pendapatan asli desa dan program bantuan lainnya seperti bantuan Program Keluarga Harapan (PKH), Bantuan Pangan Non Tunai (BPNT) dan lain-lain. Sehingga akan terlihat dampak dan kontribusi signifikan dalam menurunkan kemiskinan Kabupaten/Kota di Provinsi Aceh.

\section{DAFTAR PUSTAKA}

Abidin, Muhammad Zainul. (2015). Tinjauan atas Pelaksanaan Keuangan Desa dalam Mendukung Kebijakan Dana Desa. Jurnal Ekonomi \& Kebijakan Publik. Vol. 6 No. 1, hlm 61-76.

Adisasmita, Rahardjo. (2008). Pengembangan Wilayah Konsep dan Teori. Graha Ilmu, Jakarta. (2011). Manajemen Pemerintah Daerah. Yogyakarta : Graha Ilmu, Jakarta.

Alimbudiono, Ria Sandra \& Fidelis Arastyo Andono. (2004). Kesiapan Sumber Daya Manusia Sub Bagian Akuntansi Pemerintah Daerah "XYZ” dan Kaitannya Dengan Pertanggungjawaban Keuangan Daerah Kepada Masyarakat: Renungan Bagi Akuntan Pendidik. Jurnal Akuntansi dan Keuangan Sektor Publik. Vol. 05 No. 02. Hal. 18-30.

Arsyad, Lincolin. (1999). Pengantar dan Perencanaan Pembangunan Ekonomi Daerah. Edisi Pertama. BPFE, Yogyakarta. . (2004). Ekonomi Pembangunan. STIE YKPN, Yogyakarta. (2005). Pengantar Perencanaan Pembangunan Ekonomi Daerah, Edisi 2. BPFE, Yogyakarta. (2010). Ekonomi Pembangunan.UPP STIM YKPN,Yogyakarta. 
Arifin, Z. (2009). Metodologi Penelitian Pendidikan. Lentera Cendikia, Surabaya.

Asrianti. (2017). Pengaruh Pertumbuhan Ekonomi, Pengangguran dan Belanja Pemerintah terhadap Tingkat Kemiskinan di Indonesia. Fakultas Ekonomi dan Bisnis Islam. Universitas Islam Negeri Alaudin Makassar.

\section{4}

Astuti, Prihartini Budi. (2013). Efektivitas dan Pengaruh PNPM Mandiri Perdesaan, Alokasi Dana Desa, Pendapatan Asli Desa dan Jumlah Penduduk Terhadap Jumlah Kepala Keluarga Miskin di Kabupaten Kebumen Tahun 2009-2011. Fokus Bisnis. Volume 12, No. 2.

Awang, Azam. 2010, Implementasi Pemberdayaan Pemerintah Desa, cetakan I. Pustaka Pelajar, Yogyakarta.

Azwardi dan Sukanto. (2014). Efektivitas Alokasi Dana Desa dan Kemiskinan di Provinsi Sumatera Selatan. Jurnal Ekonomi Pembangunan. Volume 12, No.1:29-41. ISSN1829-25843.

Azwar, Saifuddin. (2004). Metode Penelitian. Pustaka Pelajar, Yogyakarta.

Bank Indonesia (2012). Definisi Produk Domestik Regional Bruto.

Badrudin, Rudi. (2012). Ekonomi Otonomi Daerah. Yogyakarta : UPP STIM YKPN.

Badan Pusat Statistik. (2010-2017). Statistik Indonesia, BPS Jakarta Indonesia.

Badan Pusat Statistik Provinsi Aceh. (2009). Definisi Produk Domestik Regional Bruto (PDRB). . (2010). Definisi Kemiskinan. . (2017). Laporan Perekonomian. . (2017). Provinsi Aceh Dalam Angka.

Bappenas. (2004). Rencana Strategik Penanggulangan Kemiskinan di Indonesia. Bappenas : Jakarta.

Bateman, Thomas S, dan Snell, Scott A. (2014), Management, Alih Bahasa : Ratno Purnomo dan Willy Abdillah McGraw-Hill Education (Asia) dan Salemba Empat, Jakarta.

Bempah, Ridwan (2013). Analisis Alokasi Dana Desa Dalam Meningkatkan Pendapatan Penduduk Miskin di Kecamatan Poso Pesisir Kabupaten Poso. E-Jurnal Katalogis, Vol. 1 No. 2, April 2013: Hlm. 55-66.

Boediono. (2009). Teori Pertumbuhan Ekonomi. BPFE, Jogyakarta. 
Certo, S.C. (1997). Modern Management Diversity, Quality, Ethics, And The Global Environment. Seventh Edition. New Jersey : Prentice Hall International, Inc.

Delanno, Galuh Fajar dan Deviani. (2013). Pengaruh Kapasitas SDM, Pemanfaatan TI dan Pengawasan Keuangan Terhadap Nilai Iinformasi Pelaporan Keuangan Pemerintah Daerah. Jurnal WRA.

Fattah, Nanang. (2009). Landasan Manajemen Pendidikan. hal. 49. PT Remaja Rosdakarya, Bandung.

Fitri, Reni Mustika. (2012). Pengaruh Kualitas Sumber Daya Manusia, Pertumbuhan Ekonomi, dan Rasio Gender Terhadap Tingkat Kemiskinan di Provinsi Sumatera Barat. Jurnal Ekonomi Pembangunan Fakultas Ekonomi Universitas Negeri Padang.

Ghozali, Imam. (2011). Ekonometrika: Teori, Konsep dan Aplikasi dengan SPSS 17. Badan Penerbit Universitas Diponegoro, Semarang.

(2013). Aplikasi Analisis Multivariate dengan Program IBM SPSS19. Badan Penerbit Universitas Diponegoro, Semarang.

Gujarati, Damodar. (2003). Ekonometri Dasar. Terjemahan: Sumarno Zain. Erlangga, Jakarta. (2004). Basic Econometrics, 4rd Edition. International Edition Mc.Graw Hill, Singapore. . (2006). Dasar-Dasar Ekonometrika. Erlangga, Jakarta.

Gujarati, Damodar dan Dawn C. Porter. (2009). Basic Econometric 5th Edition. McGraw -Hill: New York.

. (2012). Dasar-dasar Ekonometrika Buku 2. Edisi 5. Raden Carlos Mangunsong (penj.). Salemba Empat, Jakarta.

Gujarati. Damodar N dan down C. Porter. 2012 Dasar-dasar Ekonometrika. Jakarta. Salemba Erlangga.

Gumilang, Muhammad Fajar. (2017). Analisis Dampak Alokasi Dana Desa terhadap Kemiskinan di Kabupaten Bogor. Fakultas Ekonomi dan Manajemen. Institut Pertanian Bogor.

Handra, Hefrizal. Dr. Machfud Sidik.(2016). Dana Desa dan Penanggulangan Kemiskinan. Analisa Kebijakan Kolaborasi Masyarakat dan Pelayanan untuk Kesejateraan (KOMPAK). Jakarta.

Kementerian Keuangan Republik Indonesia. (2017). Buku Pintar Dana Desa.

Khomsan, Ali. et al. (2015). Indikator Kemiskinan dan Misklasifikasi Orang Miskin. Yayasan Pustaka Obor Indonesia, Jakarta.

Kuncoro, Mudrajad. (2003). Metode Riset untuk Bisnis dan Ekonomi. Erlangga, Jakarta. 
Kuncoro, Mudrajad. (2004). Otonomi dan Pembangunan Daerah: Reformasi, Perencanaan, Strategi, dan Peluang. Jakarta: Erlangga.

(2006). Ekonomika Pembangunan : Teori, Masalah, dan Kebijakan. STIM YKPM, Yogyakarta.

. (2010). Masalah, Kebijakan dan Politik, Ekonomika Pembangunan Edisi Ke-5. Erlangga, Jakarta.

Kuncoro, M. (2012). Perencanaan Daerah: Bagaimana Membangun Ekonomi Lokal, Kota dan Kawasan. Salemba Empat, Jakarta.

Kuncoro, Engkos Achmad dan Riduan. (2013). Metode Riset untuk Bisnis dan Ekonomi Edisi 4. Erlangga, Jakarta.

Kurniawati, Dwi Pratiwi, dkk. (2013). Pemberdayaan Masyarakat di Bidang Usaha Ekonomi (Studi pada Badan Pemberdayaan Masyarakat Kota Mojokerto) Jurnal Administrasi Publik. Jurnal Administrasi Publik (JAP), Vol. I, No. 4, Hal 9-14.

Kusnadi. (2006). Filosofi Pemberdayaan Masyarakat Pesisir. Humaniora, Bandung.

Krismanti, T.W (2009). Analisis Pengaruh Infrastruktur Ekonomi Dan Sosial Terhadap Produktivitas Ekonomi di Indonesia. Departemen Ilmu Ekonomi Fakultas Ekonomi dan Manajemen Institut Pertanian Bogor.

Lalira, Dianti. Dkk. (2018). Pengaruh Dana Desa dan Alokasi Dana Desa Terhadap Tingkat Kemiskinan di Kecamatan Gemeh Kabupaten Kepulauan Talaud. Jurnal Berkala Ilmiah Efisiensi. Jurusan Ekonomi Pembangunan, Fakultas Ekonomi dan Bisnis, Universitas Sam Ratulangi, Manado. Volume 18 No. 04 Tahun 2018.

Mahulete, U. K. (2016). Pengaruh PAD Dan DAU Terhadap Belanja Modal Di Kabupaten/Kota Provinsi Maluku Pada Tahun 2013-2015. Universitas Muhammadiyah Malang.

Maipita, Indra. (2013). Simulasi Dampak Kenaikan Upah Minimum Tehadap Tingkat Pendapatan dan Kemiskinan. Jurnal ekonomi dan Keuangan. Vol. 17. No.3.

Mala Sari, Intan \& M. Faisal Abdullah (2017). Analisis Ekonomi Kebijakan Dana Desa Terhadap Kemiskinan Desa Di Kabupaten Tulungagung. Fakultas Ekonomi dan Bisnis Universitas Muhammadiyah Malang. Jurnal Ekonomi Pembangunan Vol.15, No.01 Juni 2017.

Martowardojo, Agus D.W. (2012). Satu Dasawarsa Implementasi Otonomi Daerah: Dalam Perspektif Desentralisasi Fiskal. 2-4 Oktober 2012 Kongres ISEI Ke-XVIII, Yogyakarta.

Mardiasmo. (2004). Otonomi dan Manajemen Keuangan Daerah. Andi, Yogyakarta. 
Masika, R dan Sally, Baden.(1997) Infrastructure and Poverty: A Gender Analysis. Institue of Development Studies. Report No. 51. June 1997.

Matindas, Rudolf Wennemar. (2002). Manajemen Sumber Daya Manusia, Lewat Konsep Ambisi, Kenyataan dan Usaha. Edisi II, Grafiti, Jakarta.

Mardikanto, totok dan Poerwoko Soebiato.(2013). Pemberdayaan Masyarakat Dalam Perspektif Kebijakan Publik. Edisi Revisi. Alfabeta, Bandung.

Nachrowi, D. Dan Usman, Hardius. (2006). Pendekatan Populer dan Praktis Ekonometrika untuk Analisis Ekonomi dan Keuangan. Lembaga Penerbit Fakultas Ekonomi Universitas Indonesia, Jakarta.

Ndraha, Taliziduhu. (2005). Teori Budaya Organisasi, Cetakan Pertama. $\quad$ PT. Rineka Cipta, Jakarta.

Nizar, R. (2014). Analisis Determinasi Jumlah Penduduk Miskin Kabupaten/Kota di Provinsi Sulawesi Tengah Tahun 2009-2012. Universitas Mulawarman, Makassar.

Notoatmodjo, Soekidjo. (2009). Pengembangan Sumber Daya Manusia. Rineka Cipta, Jakarta. . (2010). Metodologi Penelitian Kesehatan. Rineka Cipta, Jakarta.

Nuraliyah. (2011). Peran Pengembangan Infrastruktur Dalam Pengentasan Kemiskinan di indonesia: jawa dan luar jawa. Sekolah Pascasarjana Institut Pertanian Bogor.

Nuraini, I. (2017). Kualitas Pertumbuhan Ekonomi Daerah Kabupaten / Kota di Jawa Timur, 79-93.

Nurcholis, H. (2011). Pertumbuhan dan Penyelenggaraan Pemerintah Desa. Erlangga, Jakarta.

Nurwati, Nunung. (2008). Kemiskinan: Model Pengukuran, Permasalahan, dan Alternative Kebijakan. Jurnal Kependudukan Padjajaran. Vol.10.No.1; Januari. Hal.1-11.

Peraturan Menteri Dalam Negeri Nomor 37 Tahun 2007 tentang Pedoman Pengelolaan Keuangan Desa.

Peraturan Pemerintah Republik Indonesia Republik Indonesia Nomor 43 tahun 2014 Tentang Peraturan Pelaksanaan Undang-Undang Republik Indonesia Nomor 6 tahun 2014 Tentang Desa.

Peraturan Pemerintah Republik Indonesia Republik Indonesia Nomor 60 Tahun 2014 Tentang Dana Desa.

Peraturan Pemerintah Republik Indonesia Republik Indonesia Nomor 60 Tahun 2014 Tentang Dana Desa yang bersumber dari anggaran pendapatan dan belanja negara. 
Peraturan Pemerintah Republik Indonesia Republik Indonesia Nomor 72 Tahun 2004 Tentang Alokasi Dana Desa .

Peraturan Pemerintah Republik Indonesia Republik Indonesia Nomor 72 tahun 2005 Pasal 68 (c) Tentang desa; bagian dari dana perimbangan keuangan pusat dan daerah.

Peraturan Pemerintah Republik Indonesia Republik Indonesia Nomor 22 Tahun 2015 tentang Perubahan Atas Peraturan Pemerintah Republik Indonesia Nomor 60 Tahun 2014 Tentang Dana Desa Yang Bersumber Dari Anggaran Pendapatan Dan Belanja Daerah.

Peraturan Pemerintah Republik Indonesia Republik Indonesia Nomor 43 Tahun 2014 tentang Peraturan Pelaksanaan Undang-Undang Republik Indonesia Desa.

Peraturan Menteri Keuangan Republik Indonesia Nomor 241 Tahun 2014 Pasal 1 tentang Pelaksanaan Pertanggungjawaban Transfer ke Daerah dan Dana Desa.

Permendes Nomor 5 Tahun 2015 Tentang Penetapan Prioritas Penggunaan Dana Desa Tahun 2015.

Purnama, Nadia Ika (2016). Analisis Pengaruh Pertumbuhan Ekonomi Terhadap Tingkat Kemiskinan di Sumatera Utara. Jurnal Fakultas Ekonomi dan Bisnis Universitas Muhammadiyah Sumatera Utara.

Prasetyo, Yudhi \& Gregorius Nasiansenus Masdjojo. (2014). Implementasi Kebijakan Alokasi Dana Desa di 10 Desa Wilayah Kecamatan Rembang Kabupaten Rembang. Jurnal Administrasi Publik. Vol. 1 No. 6, hlm 302-319.

Prasetyanto, PP \& Eko (2012). Dampak Alokasi Dana Desa Pada Era Desentralisasi Fiskal Terhadap Perekonomian Daerah di Indonesia. Disertasi. IPB, Bogor.

Ravallion, M. (2001). Growth, Inequaty and Poverty : Looking Beyond Averages. Policy Research Working Paper 2258. The Worl Bank.

Rini, Ayu Setyo dan Lilik Sugiharti (2016), Faktor-Faktor Penentu Kemiskinan Di Indonesia: Analisis Rumah Tangga. Fakultas Ekonomi dan Bisnis, Universitas Airlangga. Jurnal Ilmu Ekonomi Terapan. Desember 2016; 01(2): 17-33 ISSN 2085-4617.

Rusdarti, Sebayang \& Lesta Karolina (2013). Faktor-Faktor Yang Mempengaruhi Tingkat Kemiskinan di Provinsi Jawa Tengah. Jurnal Economia. Volume 9, No.1.

Rusydi, Muhammad (2012). Pengaruh Alokasi Dana Desa terhadap Kesejahteraan Masyarakat desa di Kabupaten Takalar. Jurnal Fakultas Ekonomi Unismuh Makassar. JEB-Jurnal Ekonomi Balance Volume 8 No. 2 Desember 2012 ISSN 1858-2192-152. 
Sajogyo. (1997). Kemiskinan dan Kebutuhan Minimum Pangan. Lembaga Penelitian Sosiologi Pedesaan, Bogor.

Samuelson, Paul A. \& William D. Nordhaus. 1994. Makroekonomi. Edisi keempat belas. Penerbit Erlangga. Jakarta.

Santoso, Singgih. (2007). Statistik Deskriptif: Konsep dan Aplikasi dengan Microsoft Exel dan SPSS. ANDI, Yogyakarta.

Sanjaya, Wina (2009). Perencanaan dan Desain Sistem Pembelajaran. hal. 121. Kencana, Jakarta.

Saputra, Whisnu Adhi. (2011). "Analisis Pengaruh Jumlah Penduduk, PDRB, IPM, Pengangguran Terhadap Tingkat Kemiskinan di Kabupaten / Kota Jawa Tengah". Universitas Diponegoro, Semarang.

Sasana, Hadi. (2006). Analisis dampak Desentralisasi Fiskal Terhadap Pertumbuhan Ekonomi di Kabupaten/Kota Provinsi jawa Tengah. Dinamika Pembangunan Vol. 3 No. 2/ Desember 2006 :145-170.

Setianingsih, Irma. (2016). Kontribusi Dana Desa dalam Menurunkan Angka Kemiskinan di Kabupaten Melawi. Jurnal Untan.

Setiadi, Elen, (2006). Pengaruh Pembangunan Infrastruktur Dasar Terhadap Pertumbuhan Ekonomi Regional Indonesia (8 Provinsi di Sumatera). FEUI, Jakarta.

Setyowati, Eni. (2018) Analisis Pengaruh Produk Domestik Regional Bruto (PDRB), Pendidikan dan Pengangguran Terhadap Kemiskinan Kabupaten/Kota Jawa Tengah Tahun 2011 - 2015. Tesis, Universitas Muhammadiyah Surakarta.

Setiyawati, Anis dan Ardi Hamzah. 2007. Analisis Pengaruh PAD, DAU, DAK dan Belanja Pembangunan Terhadap Pertumbuhan Ekonomi, Kemiskinan, dan Pengangguran: Pendekatan Analisis Jalur. Jurnal Akuntansi dan Keuangan Indonesia, vol 4, No. 2, Desember 2007.

Silalahi, Doni. Dkk. (2014). Analisis Ketahanan Pangan Provinsi Sumatera Utara dengan Metode Regresi Data Panel. Jurnal Saintia Matematika. Vol. 02, No. 03 (2014), pp. 237-251. ISSN: 2337-9197.

Siregar H, Wahyuniarti D. (2008). Dampak Pertumbuhan Ekonomi Terhadap Penurunan Jumlah Penduduk Miskin. Jurnal Ilmiah.

Sukirno, Sadono. (1985). Beberapa Aspek Dalam Persoalan Pembangunan Daerah. LP-FEUI, Jakarta. (2000). Makro Ekonomi Modern. PT. Raja Grafindo Persada, Jakarta. . (2004). Makroekonomi Teori Pengantar. PT. Raja Grafindo Persada, Jakarta. 
(2005). Pengantar Makro Ekonomi. PT. Raja Grafindo Persada, Jakarta.

Suliswanto, M. S. W. (2010). Pengaruh Produk Domestik Bruto (PDB) dan Indeks Pembangunan Manusia (IPM) terhadap angka kemiskinan di Indonesia. Jurnal Ekonomi Pembangunan. Vol. 8, No.2. hlm: $357-366$.

Sumaryadi, I Nyoman (2005) Perencanaan Pembangunan Daerah Otonom dan Pemberdayaan Masyarakat. Citra Utama, Jakarta.

Suryaningrat, Bayu. (2014). Pemerintahan Administrasi Desa dan Kelurahan. Rineka Cipta, Jakarta.

Survey Bank Indonesia (2017), Tentang Potret Dana Desa di Provinsi Aceh. https://www.kompasiana.com/cangkoiburong/.../potret-dana-desa-di-provinsi-aceh?diaksesdesember-2018.

Supomo, Bambang dan Nur Indriantoro (2002). Metodologi Penelitian Bisnis, Cetakan Kedua. BFEE UGM, Yogyakara.

Supranto, J. (2003). Metode Riset Aplikasi Dalam Pemasaran. Edisi Revisi Ketujuh. Rineka Cipta, Yogyakarta.

Susilowati, Nilam Indah, et al. (2017). Pengaruh Alokasi Dana Desa , Dana Desa, Belanja Modal, dan Produk Domestik Regional Bruto Terhadap Kemiskinan Kabupaten/Kota Di Jawa Timur. Jurnal Ilmu Ekonomi Vol 1 Jilid 4/Tahun 2017 Hal. 514-526.

Syachbrani, Warka. (2012). Akuntansi dan Akuntabilitas Pemerintah Desa. Tugas Akhir Mata Kuliah. Program Magister sains Akuntansi. Fakultas Ekonomika dan Bisnis. Universitas Gajah Mada, Yogyakarta.

Undang-Undang Republik Indonesia Republik Indonesia Nomor 6 Tahun 2014 tentang Desa.

Undang-Undang Republik Indonesia Republik Indonesia Nomor 22 Tahun 1999 tentang Pemerintahan Daerah.

Undang-Undang Republik Indonesia Republik Indonesia Nomor 23 Tahun 2014 tentang Pemerintahan Daerah.

Undang-Undang Republik Indonesia Republik Indonesia Nomor 25 Tahun 1999 Tentang Perimbangan Keuangan antara Pemerintah Pusat dan Daerah.

Undang-Undang Republik Indonesia Republik Indonesia Nomor 32 Tahun 2004 Tentang Pemerintahan Daerah

Tangkumahat, Feiby Vencentia., et al. (2017). Dampak Program Dana Desa terhadap Peningkatan Pembangunan dan Ekonomi di Kecamatan Pineleng Kabupaten Minahasa. Jurnal Agri-Sosio Ekonomi Unsrat, ISSN 1907-4298 Volume 13 Nomor 2A, Juli 2017 : 335 - 342. 
Tanzeh, Ahmad (2009). Pengantar Metode Penelitian. Teras :Yogyakarta

Todaro, Michael P. (1995). Ekonomi untuk Negara berkembang; suatu Pengaturan tentang Prinsipprinsip, masalah dan kebijakan dan pembangunan . Edisi Ketiga. Bumi Aksara, Jakarta.

. (2000). Pembangunan Ekonomi di Dunia Ketiga. Erlangga, Jakarta.

(2006). Pembangunan Ekonomi di Dunia Ketiga. Erlangga, Jakarta.

Todaro, Michael P. and Smith, Stephen C. (2006). Pembangunan Ekonomi. Jilid 1. Edisi 9. Alih Bahasa. Erlangga, Jakarta.

. (2011). Pembangunan Ekonomi. Edisi 11. Erlangga, Jakarta.

Thomas, (2013). Pengelolaan Alokasi Dana Desa Dalam Upaya Meningkatkan Pembangunan Di Desa Sebawang Kecamatan Sesayap Kabupaten Tana Tidung. eJournal Pemerintahan Integratif, 2013, 1 (1): 51-64 ISSN 0000-0000, ejournal.pin.or.id.

Tulusan, Femy M.G. dan Very Y Londa. (2014). Peningkatan Pendapatan Masyarakat Melalui Program Pemberdayaan di Desa Lolah II Kecamatan Tombariri Kabupaten Minahasa. Jurnal LPPM Bidang EkoSosBudKim. Volume 1, No. 1.

Wahyudiono, Emil. (2010). Faktor Yang Mempengaruhi Kemiskinan Desa di Kabupaten Jember. Tesis S2. Universitas Jember.

Warsilan, dkk. Peranan Infrastruktur terhadap Pertumbuhan Ekonomi dan Implikasi pada Kebijakan Pembangunan. Jurnal Fakultas Ekonomi. Universitas Mulawarman Samarinda ISSN 0215-8175 | EISSN 2303-2499. MIMBAR, Vol. 31, No. 2 (Desember, 2015): 359-366.

Widjaja, HAW (2003). Pemerintahan Desa/Marga. PT. Raja Grafindo Persada. Jakarta. (2010). Komunikasi: Komunikasi dan Hubungan Masyarakat. Bumi Aksara, Jakarta.

Widarjono, Agus. (2007). Ekonometrika : Teori dan Aplikasi Untuk Ekonomi dan Bisnis. Ekonisia, Yogyakarta.

. (2010). Analisis Statistika Multivariate Terapan. UPP STIM YKPN, Yogyakarta. . (2011). Ekonometrika Pengantar dan Aplikasi. UPP STIM YKPN, Yogyakarta.

Winarno, Wing Wahyu.(2007). Analisis Ekonometri dan Statistika dengan Eviews. STIM YKPN, Yogyakarta. 
Wrihatnolo, Randy R \& Dwijdowijoto, Riant Nugroho (2006). Manajemen Pembangunan Indonesia : Sebuah Pengantar dan Panduan. Elex Media Komputindo, Jakarta.

World Bank. (2006). Era Baru dalam Pengentasan Kemiskinan di Indonesia diakses melalui http://sofian.staff.ugm.ac.id/artikel/Ikhtisar-Laporan-BD-ttgKemiskinan-di-Indonesia.pdf.

Yani, M. (2012). Manajemen Sumber Daya Manusia. Mitra Wacana Media, Jakarta. 